\title{
The Impacts of Foreign Direct Investment on Economic Growth in Tanzania from 1995 To 2016
}

\author{
Aneth Luisenyi Sunford Urio \\ Msc. in Accounting \& Finance \\ Cyprus International University Nicosia \\ TRNC Mersin 10 via Turkey
}

\begin{abstract}
The study is guided by one objective which is to examine the impact of foreign direct investment to Tanzania economy from 1995 to 2016. The collected quantitative data were analyzed through E views while qualitative data, were analyzed through content analysis in which various themes were developed for data presentation and analysis. The findings through variables used including human capital, infrastructure, trade openness and FDI itself revealed the presence of impacts in which Foreign Direct Investment has on growing economy of Tanzania especially from 1990s where the country put effort in having trade openness. But also, in a way to determine economic growth, FDI resulted economic growth through transferring technology, creation of employment to many people, generating revenue to the government through taxes, contribution to social security fund and so on, provision of the needed capital to the country, creation environmental for business competition in the country, improvement of labor skills, determining trade integration and market access and changing the way domestic firms operate.
\end{abstract}

Keywords: Foreign Direct Investment (FDI), Gross Domestic Product (GDP), International Monetary Fund (IMF), Tanzania Investment Center (TIC), Transnational Corporations (TC), United Nations Conference on Trade and Development (UNCTD), United Republic of Tanzania (URT), United States Agency for International Development (USAID), World Bank (WB), Government Expenditure (GOVEXP), Logarithm of human capital secondary school enrollment (LHC), Logarithm of infrastrumcture (LINFS), Natural Resources (NR), Trade Openness(OPEN)

\section{Introduction}

As defined by Bjorvan (2000) FDI as an investment is made by acquiring the lasting interests in which foreign enterprise has the purpose of having effective voice particularly in its process of management. Hence, it involves investment from one country into another country especially with the companies (Multinational companies) rather country, the companies involves itself in establishing operation by acquiring tangible assets which can be the stake in other business. In the transferring process, FDI does not only transfer ownership but also complementary factors to capital which can be technology, management together with organization skills. The addressed problem under this study is the impacts of Foreign Direct Investment on Economic growth in Tanzania since 1995 to 2016. The addressed problem came due to the currently striving of the Tanzania government to improve its economic growth through Foreign Direct Investment while there are emerging policy makers, researchers and politicians who are questioning the contributions of Foreign Direct Investment to economic growth. In determining the impact of FDI, the study is based on six variables including foreign direct investment, government expenditure in FDI, secondary school enrollment (human capital), infrastructure that attract FDI and also its development due to FDI, trade openness as well as natural resources.

Many studies have been done under FDI worldwide, but none has concentrated on Tanzania as one of the countries that has been trying to attract FDI since her independence in 1961. Despite the setback from 1967 to 1985 in which the government adopted socialism due to the Arusha Declaration, an agreement was made by government of Tanzania, International Monetary Fund (IMF) and World Bank through Structural Adjustment Programme. Economic Recovery Programme came into action withy broad range of policies which intended to liberalizing both internal and external trade, unifying the rate of exchange, reviving exports, stimulating the saving of domestic together with restoring fiscal stability of the country's economy. 
The study provides empirical evidence concerning the presence of relationship between Foreign Direct Investment (FDI) and economic growth in Tanzania from 1995 to 2016. Based on that empirical evidence, the contribution of Foreign Direct Investment (FDI) to economic growth of Tanzania was revealed so as to know how exactly, Foreign Direct Investment is related to it.

\section{Literature review}

Since the impact of Foreign Direct Investment on economic growth have not only limited to developing but also FDI has impact on economic growth of developed countries. Therefore, this part of empirical literature review will put efforts on analyzing the impact which Foreign Direct Investment has on economic growth of developing countries.

According to the United Nations' Secretary General (2003), Foreign Direct Investment has the significant role in ensuring the growth of economy in those countries in which FDI operates. The Secretary General (2003) summarized the impact of FDI on the growth of economy in developing countries to be the creation of jobs which reduce unemployment rate, increasing productivity in the countries and enhancing the export and transfer of technology which in long run the economic growth of developing countries will be ensured.

According to the one of the influential work which was undertaken by Borenztein, De Gregorio and Lee (1998) on the impact of Foreign Direct Investment on economic growth based over the past ten years. The study was undertaken on 69 developing countries and the finding from the study revealed the presence of impact that Foreign Direct Investment put them on economic growth. According to them, Foreign Direct Investment ensure economic growth of the country since it is an essential vehicle in which technology can be transferred and they concluded that, with such king of investment, domestic investment become much powered for the better result. Also, Borenztein, De Gregorio and Lee (1998) reported Foreign Direct Investment to be necessary ingredient for economic growth of the developing countries through human capital as enhanced by interaction in that host countries.

According to the study of Abala (2014) which was undertaken in Kenya, the study reported Foreign Direct Investment as the main driver of both economic growths in Kenya as well as attraction of Foreign Direct Investment in Kenya too. The study reported Foreign Direct Investment in mining sectors to be insignificant to economic growth of the country while the Foreign Direct Investment in manufacturing sector was reported to be significant in determining the growth of economy of Kenya. The study reported the factors behind for FDI in manufacturing sector to be significant in economic growth as the nature of FDI attraction in Kenya which is market seeking in manufacturing sector which favor that sector into highly contributing to economic growth which is high compared to contribution brought by mining sector, tourism sector and other service sectors.

In Nigeria, the study on the impact of Foreign Direct Investment of economic growth was undertaken by Onakoya (2012). The study was undertaken on manufacturing sectors and agricultural sector in order to examine the impact of FDI on the growth of Nigeria economy. The finding revealed the presence of impact of Foreign Direct Investment on economic growth where the significant output on economy was reported to be contributed by Foreign Direct Investment but in the case of economic growth, the FDI in those sectors were reported to be differ where on manufacturing sector the contribution on economic growth was insignificant while in agriculture sector, the impact was found to be significant in growing economy. While Anyanwu (2007) which studied the relationship between FDI and economic growth in Nigeria, reported communication sector to be the highest and potential sectors in growing economy due to FDI on that sector and it was reported to be in multiple of that of the Oil sector while FDI in manufacturing sectors was reported to be negatively in growing the economy of Nigeria.

In Tanzania, Foreign Direct Investment has been reported to have influence in growing economy of the country by forming capital even the large share of it is held by domestic investment where between 1999-2004, about 5 percent of GDP was contributed by Foreign Direct Investment while the contribution to Gross Fixed Capital Formation was about 25.7 (UNCTAD, 2000). Also, the economic growth in Tanzania is reported to be contributed by Foreign Direct Investment through technology (machinery, equipment and tools, technical skills and process-related technologies), through revenue generation where Foreign Direct Investment provides tax revenue for country's economic growth as occurred in 2001, 2002 and 2003 where the companies that have been privatized contributed about 6.7 percent, 9.1percent and 9.2 percent of all total revenue of tax for those years Other impact of FDI on economic growth were revealed by the study of Lenka and Sharma (2014) who came with the study entitled "FDI as a main determinant of economic growth," according to them, FDI determine the growth of economy through influencing the GDP growth.

232 
According to them, if FDI to the country is increased also there will be the increase of both capital formation and the gap between domestic saving and investment will be filled. Therefore, with the increase of that domestic investment and saving, capital formation also get into increasing which them determine the increase of production of the host country, on the basis of that increase of production, export of that host country will be increased and that country will be in a good position to acquire more foreign currency from other part of the world which finally will increase GDP and per capital income for growing economy of the country (Lenka and Sharma (2014).

For Foreign Direct Investment to have positive impact on economic growth of a country does not mean it has no negative impact on economic growth. According to Jones (1996) Foreign Direct Investment tends to displace local firm since the Multinational Enterprises are too big to compete with local firms as the result of this, developed countries which are owning those MNC get benefitted with what practiced by Foreign Direct Investment. Also with the presence of weak legislations and regulations in many developing countries, the FDI operate as a source of capital flight from developing countries to developed countries. Other negative impact of FDI on economic growth was reported by the study of Barro (2002) to be large scale environment damage as what occurring in Tanzania especially in mining sector for the interest of the developed countries.

According to the study of Ek (2007) which was entitled "the Impact of FDI on Economic Growth: The Case of China" the study revealed the impact of FDI on the economic growth of China from 1994 to 2003 to be in positive way. According to that study, FDI has positive impact in growing economy of China due to the fact that FDI in Chinise's economy is serving as a tool in which new technologies have been transferred from one country to another country (China) as the result of such transformation of technologies, the output and Gross Domestics Product of China increased too. According to Ek (2007) the positive impact of FDI on the level of GDP have been statistically significant at the level of 6 percent

\section{International Dependency Theory}

This theory of as an extension of Marxist theory was popular especially in the 1970s and also in the early of 1980s. The international dependence theory argues that the weak economic growth exists in many developing countries occurs due to the dominance of both developed countries and Multinational Corporation in developing countries. According to this theory, developing countries depend highly on them especially for both market as well as capital, as the result of these developing countries tends to receive very small portion of what expected from Multinational Corporation which operate as Foreign Direct Investment. According to Cohen (1973) Multinational Corporation (MNC) from developed countries tend to exploit national resource found in less developed countries by getting food and raw material in a cheap way and in addition to that developing countries do not have a control on the distribution of the value added to those products which are traded between them and developed countries as the result, developing countries have been exploited deeply which make them dependent to their exploiter who are developed countries. Therefore, the international dependence theory argues that, with this dependence relationship, developing countries fail to grow their economies. According to Elkan (1995) who argued on international dependence theory says, for developing countries to attain economic growth, Foreign Direct Investment from developed countries is not a good way and the only suitable way for developing countries to attain economic growth is through breaking up the dependence relationship between them.

On the basis of the arguments brought by international dependence theory, the study on the impact of Foreign Direct Investment (FDI) on economic growth in Tanzania from 1995 to 2017 applied that theory so as to determine whether there was dependence on certain groups or countries in the operation of FDI in the country and then, the study of such kind of FDI was studied closely to identify their impact on the economic growth of Tanzania from 1995 to 2017. This kind of studying was as important in the country growth of economy as influenced with the presence of FDI which started to be operated from 1995 to date

\section{New growth theory}

The theory of New Growth came in the 1990s as an effort to explain economic growth performance especially in developing countries. The theorists under New Growth Theory were Romer (1986), Lucas (1988) and then Howitt and Aghion (1992). According to this theory, in developing countries, economy tends to growth due to increasing in return in the usage of knowledge rather than labour and capital. Also, this theory of New growth emphasizes on availability of two critical channel for Foreign Direct Investment that determine growth of economy in a country where the one come through the effect on the range of available products and the second comes through the impact on the stock of knowledge accessed for research and development. 
On the basis of this theory, growth of economy may occur through diffusion of technology, creation of comparative advantages that lead technological progress as reported by Romer (1986) that technological progress to be the main engine of growth of economy in developing countries, also by strengthen human capital. According to Helpman (1991) Foreign Direct Investment in countries may increase competition and innovation which then result to technological progress and increasing productivity which ends with increasing growth of economy in long run of the country.

Since this study concerns with studying the impact which FDI has on the growth of Tanzania economy from 1995-2017, hence the application of this theory was helpful for this study due to the fact that the theory helped to examine those impact of FDI particularly on how economic growth happen as the result of FDI which based on the application of technologies which generated new ideas and innovations which acts as another force towards economic growth of the country.

\section{The Internationalization Theory}

The Internationalization theory focuses on explaining how and why there is growth of transnational companies engage in overseas activities especially on what motivate them to engage in (FDI). Buckley and Casson (1976) were the first one in developing this theory; other theorists who came next after them were Hannart (1982) and Casson (1983). Internationalization theory argues that there are two determinants for Foreign Direct Investment; one is removal of business competition and the other determinant is the advantages which those transnational companies may have in particular action in which they engage in. The founders of this theory who were Buckley and Casson (1976) demonstrated that transnational companies which operate Foreign Direct Investment keep in organizing their internal activities in order to specific advantage for being exploited by them as they operate. While Hymer (1976) demonstrated what determine Foreign Direct Investment (FDI) to be only benefit that those transnational companies may have ability to exploit especially when those specific advantages of firms outweigh the relative cost of the operation in abroad.

In relation to the study on the impact of Foreign Direct Investment on growth of Tanzania economy, the internationalization theory was utilized to compare the determinants for FDI set by Tanzania government so as in attracting such FDI in a country to those determinants exposed by the theory of internationalization as addressed to be removal of business competition, exploiting advantages which those transnational companies might have in particular action in which they engage in and ability to exploit advantages especially when those firm specific advantage outweigh the relative cost of the operation in abroad. Then, the theory of internationalization in considering their determinant, the study used such theory in studying the way it influences such kind of investment and then economic growth of Tanzania.

Even through the internationalization theory will be applied in the study, there are limitations accompanied with this theory. The internationalization theory explains only determinants of FDI for transnational companies from developed without paying attention on the determinant of FDI in developing countries.

\section{Methodology}

The research design for this study was exploratory research design because with this research problem, there are few or no earlier studies to refer to so as to reveal impacts which FDI had in determine the growth of Tanzania economy from 1995 to 2016. The study area in which this study was undertaken was Tanzania as one of developing country found in East Africa. The study required to collect data from secondary source (the already collected data) due to the nature of this study as exploratory study, from sources like WB, IMF, BoT and TIC. Thus, method which was used to collect those data was documentary review or analysis. The collected data were analyzed by using E views.

The time series data to be analyzed in this study was data from 1995 to 2016 . The data was converted to quarterly base using e views software (quadratic match average). The study used multiple regression models as to determine the impact which Foreign Direct Investment put on economic growth of Tanzania from 1995 to 2016. The equation is expressed as: $\log (F D I) t / 4=\beta 0+\beta 1 \log$ (GOVEXP) $t / 4+\beta 2 l H C t / 4+\beta 3 l I N F S t / 4+\beta 4 \mathrm{NR} t / 4+$ $\beta 5 \mathrm{OPEN} t / 4$ Where $F D I$ represent foreign direct investment which is defined as foreign direct investment, net inflows (BoP, current US\$), GOVEXP denotes general government final consumption expenditure (\% of GDP), $H C$ denotes human capital which is defined as secondary school enrollments (\% net), INFS is of infrastructure which is defined as mobile cellular subscriptions, NRrepresent total natural resources rents (\% of GDP) and OPEN represent trade openness which is defined by exports and imports of goods and services (\% of GDP) 


\section{Data analysis and discussion}

Table 1: Regression results for the variables

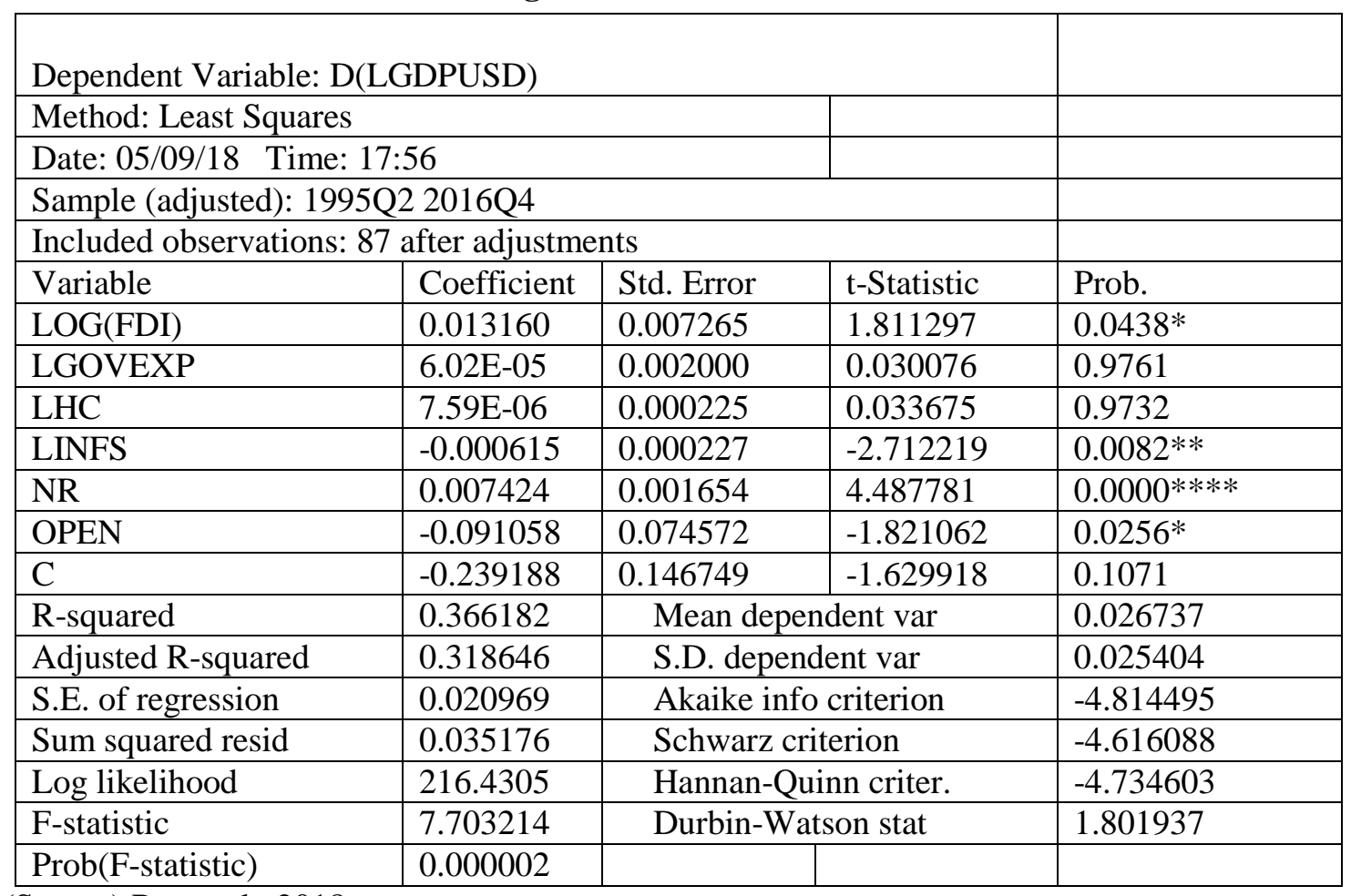

(Source) Research, 2018

The inter-relationships between the seven variables that were tested using Pearson correlation test. Lind et al (2005) affirmed that strong correlation is when $r=0.5$ to 1 or $r=-0.5$ to -1 . The results shows that all variables were correlated together at 0.01 level from the values ranges between $r=0.511$ or $r=0.9247$.

1. Foreign direct investment is positively statistically significant at 5\%. Therefore, proves the presence of economic growth in the country which determine the inflows of Foreign Direct Investment and on other side the inflows of Foreign Direct Investment determine economic growth in the country. It has been reported by Okpara (2012) that increase in 1 percent of infrastructure development determine the increase of 13.36 percent of Foreign Direct Investment in Tanzania.

2. Infrastructure is negatively significant at $1 \%$. Infrastructure has had a negative impact on foreign direct investment in the sense that, there hasn't been enough development of infrastructure since 1995 to2016 in Tanzania to influence the development of foreign direct investment.According to Tanzania Investment report (2012) reported that infrastructure has been a limitation in attracting FDI to a country, hence government set aside great investment, for the transport and utilities infrastructure that was worth of $\$ 19$ billion so as to ensure development of infrastructure as well as attracting FDI to a country in order to accelerate economic growth through the presence of Foreign Direct Investment

3. Natural resources are positively significant at $1 \%$. The contribution of natural resources through FDI has been made possible due to the technological transfer. With the transfer of technology, the production in the country has been improved both in term of quality and quantity of goods and services which determine the county ability to cope with trade competition. As the result, economic growth of the country has to be guaranteed which then has to turn and become one of the great influences for attracting Foreign Direct Investment in the country. According to Tanzania Investment Center (2012) currently, the transferred technology from Foreign Direct Investment has been a transformer for agricultural and mining sectors by 75 percent of production since that application of automation machine minimized both time and other cost of production which then resulted to increasing government revenue so as to lead the country economic growth which in return attract many foreign investors.

4. Trade openness is negatively significant at $5 \%$. 
In Tanzania, one great determinant of Foreign Direct Investment has been trade openness since after economy liberation especially in 1990s, many foreign investor have been attracted to come for FDI in Tanzania. Some of the negative impact of having many Foreign Direct Investment in a country has been a killing of local firms since FDI bring stiff competition with those local firms, other negative impacts may be unemployment to Tanzanians since FDI may come with their own labors, other is occurrence of inflation in the country if the inflow of capital is not well checked.

\section{Conclusion}

Generally, the study on the impact of Foreign Direct Investment on economic growth of Tanzania from 1995 to 2016 revealed the presence of economic growth as influenced by FDI especially from 1990s where in 1995 FDI contribution to GDP was $2.0 \%, 1996$ was $2.31 \%, 1997$ was $2.05 \%, 1998$ was $1.84 \%, 1999$ was $5.33 \%, 2000$ was 4.55\%, 2001 was $5.29 \%, 2002$ was $3.66 \%, 2003$ was $2.73 \%, 2004$ was $3.45 \%$, 2005 was 5.53\%, 2006 was $2.17 \%$, 2007 was $2.7 \%, 2008$ was $5.05 \%, 2009$ was $3.33 \%, 2010$ was $5.77 \%, 2011$ was $3.63 \%, 2012$ was $4.6 \%$, 2013 was $4.71 \%$, 2014 was $3.47 \%$, 2015 was $3.52 \%$ and 2016 was $2.88 \%$. But the attainment of such result in economic growth was highly influence by Foreign Direct Investment especially through creation of employment, transferring technology, provision of much needed foreign capital, development of labor skills, building competitive environment for business practice, trade openness, growth of various necessary sector in which FDI is imposed together with speeding up the industrialization process for continuation of the country economic growth.

\section{Limitation and direction of future studies}

Since the study was based on secondary data collection, some data were not available due to lack of information from the secondary source of data thus limiting the study to this period of only thirty one years (1995 to 2016). Despite the limitation the researcher effectively utilized the available data so as to ensure the successfully on studying the addressed research problem. For further research, the study recommend other studies to be undertaken by studying Foreign Direct Investment in each sector such as manufacturing, agriculture, mining and other sectors in which FDI is imposed in so as to determine the effect of FDI in each sector to economic growth of Tanzania. And also other study undertaken should consider other variables other than the ones used in this study to determine economic growth in a country and in a different time series.

\section{References}

Abala, D. O. (2014) foreign direct investment and economic growth: an empirical analysis of Kenyan data. DBA Africa Management Review, 4(1), 62-83.

Aghion, P. \&. (1992). A model of growth through creative destruction. Econometrics(60), 323-351.

Ahmed, S., Creanga, A. A., Gillespie, D. G., \& Tsui, A. O. (2010) Economic status, education and empowerment: implications for maternal health service utilization in developing countries. PloS one, 5(6), e11190

Amadeo, K. (2017). Hurricane Katrina Facts: Damage and Cost. The Balance, 9

Anyanwu, J. C. (1998). Why Does Foreign Direct Investment Go Where It Goes?: New Evidence From African Countries. Annals of Economics \& Finance, 13(2).Asajile, U. (2014). The Impact of Foreign Direct Investment on Economy in Tanzania 1975-2013. Dar es Salaam.

Ayanwale, A. B. (2007). FDI and economic Growth: Evidence from Nigeria.

Asajile, U. (2014). The Impact of Foreign Direct Investment on Economic Growth in Tanzania 1975-2013 (Doctoral dissertation, The Open University of Tanzania).

Asiedu, E. (2002). On the determinants of foreign direct investment to developing countries: is Africa different? World development, 30(1), 107-119

Balasubramanyam BH, S., \& Investment, D. F. D. (1996) Economic Growth in EP and IS Countries/BH Balasubramanyam, D. Sapsford. Economic Journal, (106), 434

Barro, R. J. (1996). Determinants of economic growth: A cross-country empirical study (No. w5698). National Bureau of Economic Research

Barrett, G. A., Jones, T. P., \& McEvoy, D. (1996) Ethnic minority business: Theoretical discourse in Britain and North America. Urban studies, 33(4-5), 783-809

Bevan, D. L., Bigsten, A., Collier, P., \& Gunning, J. W. (1988). Incomes in the United Republic of Tanzania during the Nyerere experiment. Trends in Employment and Labour Incomes: Case Studies on Developing countries, ILO, Geneva.

Bigsten A., \& Danielsson, A. (1999) Is Tanzania an emerging economy? Report to the OECD, Gothenburg and Lund, Sweden. 
Bjorvatn, K. (2000). Urban infrastructure and industrializationJournal of urban economics, 48(2), 205-218

Borensztein, E. D. (1998). How Does Foreign Direct Investment Affect Economic Growth? Journal of International Economic, 2(45), 35-115.

Bornschier, V. (1980) Multinational corporations and economic growth: A cross-national test of the DE capitalization thesis. Journal of Development Economics, 7(2), 191-210.

Buckley, P., \& Casson, M. (1976) the future of the multinational corporation

Cohen, B. J. (1973). The question of Imperialism

Castle, J., \& Shephard, N. (Eds.) (2009) the Methodology and Practice of Econometrics: A Festschrift in Honor of David F. Hendry. OUP Oxford Development, D. f. (2010) Growth Building Jobs and Prosperity in Developing Countries DFID

Elkan, W. (1995). An introduction to development economics (2nd ed ed.). New York: Prentice Hall.

Fintan, P. \&. (2016). Economic Growth, Foreign Direct Investment, Trade and Domestic Investment in Tanzania: Cointegration and Causality Analyses. American Journal of Business and Economic, 1(1), 3-7.

Grossman, G. M., \& Helpman, E. (1991) Trade, knowledge spillovers and growthEuropean economic review, 35(2-3), 517-526

Greenwood, D. J., \& Levin, M. (2006)Introduction to action research: Social research for social change SAGE publications

Hannart, J. F. (1988). A transaction costs theory of equity joint ventures. Strategic management journal, 9(4), 361374.Hymer, S. (1976) The international Operation of Nation Firm: A Study of Foreign Direct Investment. Cambridge: MLT Press.

Hymer, S. H. (1976). International operations of national firms MIT press.

Ito, T., \& Yabu, T. (2007)what prompts Japan to intervene in the Forex market? A new approach to a reaction functionJournal of International Money and Finance, 26(2), 193-212

KABELWA, G. (2006). Potential Impacts of FDI on Economic Development in Tanzania: Policy Dialogue for Accelerating Growth and Poverty Reduction in Tanzania. Helpman, R. (1991). Towards a dynamic economicvs, some recent development of economic theory and their application to policy. London: Macmillan.

Kale, P., \& Singh, H. (2007) Building firm capabilities through learning: the role of the alliance learning process in alliance capability and firm-level alliance success. Strategic management journal, 28(10), 981-1000

Kothari, C. R. (2004). Research methodology: Methods and techniques. New Age International

Sharma, A., \& Lenka, S. K. (2014) Authentication in online banking systems: quantum cryptography perspective. Int. J. Engineering and Technology, 5, 561-564.

Lucas Jr, R. E. (1988). On the mechanics of economic developmentJournal of monetary economics, 22(1), 3-42

Lunenburg, F. C., \& Irby, B. J. (2008)Writing a successful thesis or dissertation: Tips and strategies for students in the social and behavioral sciences. Corwin press.

Mancinger, K. M., \& Mussinger, H. L. (1999) Seven Psychological Principles You Can Use to Become a More Effective Lawyer. Tex. BJ, 62, 894.

Ngowi, H. P. (2005). Private sector delivery of urban services: benefits, obstacles and ways forward for public transport service in Dar es Salaam city, Tanzania. Eastern Africa Social Science Research Review, 21(1), 97-117.

Onakoya, A. O., Mbadugha, C. A., Aribaba, O. T., \& Ibidapo, O. O. (2012) Quality of life of primary open angle glaucoma patients in Lagos, Nigeria: clinical and sociodemographic correlates. Journal of glaucoma, 21(5), 287-295

Payne, D. M., \& Raiborn, C. A. (2001) Sustainable development: the ethics support the economics. Journal of Business Ethics, 32(2), 157-168.

Romer, P. M. (1990)Endogenous technological changeJournal of political Economy, 98(5, Part 2), S71-S102

Singh, A. (1986). Tanzania and the IMF: The analytics of alternative adjustment programmers. Development and Change, 17(3), 425-454.

Vermeulen, L., Todaro, M., de Sousa Mello, F., Sprick, M. R., Kemper, K., Alea, M. P.,\& Medema, J. P. (2008). Single-cell cloning of colon cancer stem cells reveals a multi-lineage differentiation capacity. Proceedings of the National Academy of Sciences, 105(36), 13427-13432.

(TIC), T. I. (2006). Tanzania Investment Report, 2004. Dar es Salaam: TIC.

Todaro, M. (2008) P. Dan Stephen C

Unctad, T. (2005) Development Report. United Nations, New York and Geneva

Usiri, H. (2014). Learning visit to Kenya by Executive Officer, Nronga Women Dairy Coop. Society Tanzania

Yin, R. K. (2003) Case study research: Design and methods Thousand Oaks. Sage Young, LC and Wilkinson, IR (1989)the role of trust and co-operation in marketing channels: a preliminary study. European Journal of Marketing, 23(2), 109-122. 